Cell Research(1995),5,165-179

\title{
Visualization of Golgia apparatus as an intracellular cal- cium store by laser scanning confocal microscope ${ }^{1}$
}

\author{
CUI Jie, YAN LI*, ShaOBAi XUE ${ }^{2}$ \\ Biology Department, Beijing Normal University, Beijing \\ 100875, China. \\ * Meridian Instruments (H.K. (LTD)), Unit 806, 8/F., \\ Cheung TAT Centre, 18 Cheung Lee Street, Shai Wan, \\ Hong Kong.
}

\section{ABSTRACT}

Using laser scanning confocal microscopy, we have found that the in cells loaded with fluo-3/ AM, highest intracellular $\mathrm{Ca}^{2+}$ in the perinuclear region is associated with the Golgi apparatus. The spatiotemporal subcellular distribution of $\mathrm{Ca}^{2+}$ in living human fibroblasts exposing to calcium-free medium in response to agonists has been investigated. PDGF, which releases $\mathrm{Ca}^{2+}$ from intracellular stores by inositol(1, 4, 5)-trisphosphate pathway, produced a biphasic transient rise in intracellular calcium. The initial rise was resulted from a direct release of calcium from the Golgi apparatus. Calcium could be also released from and reaccumulated into the Golgi apparatus by the stimulation of thapsigargin, an inhibitor of the $\mathrm{Ca}^{2+}$ transport ATPase of intracellular calcium store. Permeablizing the plasma membrane by $10 \mu M$ digitonin resulted in the calcium release from the Golgi apparatus and depletion of the internal calcium store. These results suggest that the Golgi apparatus plays a role in $\mathrm{Ca}^{2+}$ regulation in signal transduction.

Key words: Golgi apparatus, intracellular calcium store, fluo-3/ AM, laser scanning confocal microscopy, PDGF, thapsigargin.

1. The work is specifically dedicated to Professor Zhen YAO for his 80 - years birthday

2. Corresponding author. 


\section{INTRODUCTION}

Modulation of intracellular $\mathrm{Ca}^{2+}$ is essential for signal transduction in nonexcitable cells. Recently, video-image techniques have visualized dynamic changes in intracellular calcium $\left(\left[\mathrm{Ca}^{2+}\right]_{i}\right)$ using single cells loaded with different calcium probes. Much of the evidence shows that the subcellular changes in $\left[\mathrm{Ca}^{2+}\right]_{i}$ induced by agonists are heterogeneous in various cell types[I-3]. The intracellular calcium pool plays a fundamental role in $\mathrm{Ca}^{2+}$ homoeostasis. Although great progress has been made in identifying the important protein molecules that control the $\mathrm{Ca}^{2+}$ pool e.g., $\mathrm{Ca}^{2+}$-ATPase, ryanodine or inositol $(1,4,5)$-trisphosphate $\left(\mathrm{InsP}_{3}\right)$ receptor $\left(\operatorname{Ins} \mathrm{P}_{3} \mathrm{R}\right)$ and storage protein, the localization of internal $\mathrm{Ca}^{2+}$ stores is still much less clear in non-excitable cell for technical reasons. Up to now, there has been no anatomic co-localization of subcellular distribution of $\mathrm{Ca}^{2+}$ with specific subcellular organelles.

Confocal microscopy combined with fluorescent $\mathrm{Ca}^{2+}$ indicators offers a tool to study the intracellular sites where $\left[\mathrm{Ca}^{2+}\right]_{i}$ changes take place as a consequence of a appropriate cell stimulation. Because of the thin confocal slice of single intact living cells, it is possible to obtain detailed and reliable information about the spatial localization and rapid kinetics of the intracellular $\mathrm{Ca}^{2+}$ pools, which act as the intracellular targets of signalling systems activated by cell treatment. In the present work, with the help of laser scanning confocal microscope (LSCM) region with the highest $\mathrm{Ca}^{2+}$ concentrations is found to be located in the perinuclear cytoplasm of human fibroblasts and colocalizes with the Golgi apparatus. The results are consistent with previous work on other cell types[4-7]. Further experiments to monitor the spatiotemporal $\left[\mathrm{Ca}^{2+}\right]_{i}$ changes with platelet-derived growth factor(PDGF), thapsigargin(TG) and digitonin showed clearly that the Golgi apparatus is a functional intracellular $\mathrm{Ca}^{2+}$ pool and may play some role in $\mathrm{Ca}^{2+}$ homoeostasis. The cell nucleus always shows a remarkable response to the change in intracellular calcium concentration. The nuclear calcium can be a mark for observing the activity of internal $\mathrm{Ca}^{2+}$ stores.

\section{MATERIALS AND METHODS}

Reagents and cells

PDGF was obtained from BRL (Gaithersburg, MD) and stored as a stock solution of $0.1 \mu \mathrm{g} / \mu \mathrm{l}$ in sodium phosphate buffer at $-20^{\circ} \mathrm{C}$. Thapsigargin (Sigma Chemical Company, St. Louis, MO) was kept as a $1.54 \mathrm{mM}$ stock solution in DMSO at $-20^{\circ} \mathrm{C}$. Fluo-3 /AM and C6-NBD-ceramide were synthesized by Molecular Probes, Inc. (Eugene, OR). A human embryo lung fibroblast cell line, 2BS cells (Beijing Lung science institute, Beijing) were grown on glass coverslips in DMEM(GIBCO, Grand Island, New York) with $10 \%$ calf serum at $37^{\circ} \mathrm{C}$ in a $5 \% \mathrm{CO}_{2}$ cell incubator. Cells from 14-20 passages were used in the present experiments.

\section{Vital staining of the cells with fluo-3 /AM and C6-NBD-ceramide}

Cells were rinsed once with standard buffer ( $138 \mathrm{mM} \mathrm{NaCl}, 5.0 \mathrm{mM} \mathrm{KCl}, 0.3 \mathrm{mM} \mathrm{KH}{ }_{2} \mathrm{PO}_{4}, 0.4$ 
$\mathrm{mM} \mathrm{MgSO}_{4}, 0.3 \mathrm{mM} \mathrm{NaHPO}, 1.3 \mathrm{mM} \mathrm{CaCl} 2,0.1 \%$ D-Glucose, $20 \mathrm{mM}$ HEPES, $0.1 \%$ BSA, pH 7.2) and incubated with $10 \mu \mathrm{M}$ fluo-3/ $\mathrm{AM}$ at $37^{\circ} \mathrm{C}$ for $60 \mathrm{~min}$. The cells were then washed with standard buffer at least four times before calcium imaging. Labelling the Golgi apparatus with C6-NBD-ceramide was performed as described previously[8].

\section{Confocal microscopy}

The coverslips of the cells loaded with fluo-3 /AM were mounted in a $1 \mathrm{ml}$ chamber and incubated in standard buffer for imaging. Fluo-3 fluorescence was detected with an INSIGHT PLUS laser scanning confocal microscope system equipped with an Olympus IMT-2 inverted microscope with a $100 \times(\mathrm{NA}=1.3)$ oil objective. An argon laser was used to excited fluo-3 at 488nm. Polygons were drawn around four typical regions in a single cell for measurement of the average fluorescent intensity.

A Z-series of optical sections through a $2 \mathrm{BS}$ cell was obtained with a Z step of $0.2 \mu \mathrm{m}$, and a middle optical section was selected and captured by LSCM afterward. Then the gain of the camera was reduced so that the fluo-3 fluorescence could not be detected. The standard buffer in the chamber was removed and the cells were stained with C6-NBD-ceramide for $10 \mathrm{~min}$ : The cells were washed and incubated for another $45 \mathrm{~min}$ in the standard buffer before imaging the fluorescence of C6-NBD-ceramide of the selected section.

\section{Treatment with PDGF, thapsigargin and digitonin}

2BS cells loaded with fluo-3 /AM were incubated in $\mathrm{Ca}^{2+}$-free medium for imaging. For $\mathrm{Ca}^{2+}$. free medium, standard buffer without $1.3 \mathrm{mM} \mathrm{CaCl} 2$ was mixed with CHELEX X-100 and stirred at least $24 \mathrm{~h}$. The supernate was used as a $\mathrm{Ca}^{2+}$-free medium. PDGF, Thapsigargin and digitonin were added at the time indicated by arrows. Fluorescence intensities were recorded at 0.2 3.0 second intervals using a Dage CCD camera with an intensifier. Data were stored directly to a computer through a frame grabber and subsequently analyzed using INSIGHT-IQ analysis software.

\section{RESULTS}

\section{Association of perinuclear high $\left[\mathrm{Ca}^{2+}\right]_{i}$ with the Golgi apparatus}

Fig 1 shows a typical pseudocolor LSCM fluorescence image of a 2BS cell stained with $\mathrm{Ca}^{2+}$ probe fluo-3/AM. There is a prominent $\left[\mathrm{Ca}^{2+}\right]_{i}$ accumulation in the perinuclear area (area 1). The cell nucleus (area 2) shows a distincty lower $\left[\mathrm{Ca}^{2+}\right]_{i}$ than the perinuclear region and noticeably lower than that in the rest of cell cytoplasm (area 3, 4). In the twenty-six examined cells, nuclear $\left[\mathrm{Ca}^{2+}\right]_{i}$ is about $57.8 \pm 17.3 \%$ of perinuclear $\left[\mathrm{Ca}^{2+}\right]_{i}$, while the rest of cytoplasmic $\left[\mathrm{Ca}^{2+}\right]_{i}$ is about $73.5 \pm 8.2 \%$ of perinuclear $\left[\mathrm{Ca}^{2+}\right]_{i}$.

To examine the co-localization of $\left[\mathrm{Ca}^{2+}\right]_{i}$ with Golgi apparatus, 2BS cells were first loaded with $\mathrm{Ca}^{2+}$ indicator fluo-3 / AM. Serial optical sections were obtained by LSCM (Fig 2, left column a, c). Decreasing the amplitude of the fluorescence signal by reducing the gain of the camera so that the fluorescence of fluo-3 can not be detected, which allowed us to observe the Golgi apparatus in cells stained with C6NBD-ceramide. The fluorescence of C6-NBD-ceramide is so bright that it is possible to visualize the Golgi apparatus without interference from the fluorescence of fluo-3. A serial optical section of C6-NBD-ceramide fluorescence (Fig 2, right column b, d) reveals that the position of the highest $\left[\mathrm{Ca}^{2+}\right]_{i}$ is identical to that of the Golgi apparatus in each optical section. The results indicate that the Golgi apparatus is 
an intracellular calcium store of 2BS cell. Similar experiments in NIH3T3 cells and $\mathrm{C} 3 \mathrm{H} 10 \mathrm{~T}_{1 / 2}$ cells also indicate that the region of high perinuclear $\left[\mathrm{Ca}^{2+}\right] i$ is associated with the Golgi apparatus (data not shown).

\section{PDGF induced calcium release from the Golgi apparatus}

To determine whether the Golgi apparatus is a functional $\mathrm{Ca}^{2+}$ store, PDGF was used to induce intracellular $\mathrm{Ca}^{2+}$ release. PDGF generates $\mathrm{InsP}_{3}$ by interacting directly with phospholipase C- $\gamma \mathrm{l}$ (PLC- $\gamma 1$ ) $[9,10]$. InsP $\mathrm{P}_{3}$ mobilizes calcium from internal stores through binding to its receptor[9]. In the absence of extracellular $\mathrm{Ca}^{2+}, 5 \mu \mathrm{g} / \mathrm{ml}$ PDGF resulted in a spatial change in $\left[\mathrm{Ca}^{2+}\right] i$ in $2 \mathrm{BS}$ cells (Fig 3). In some cells ( 6 out of 15 cells), nuclear calcium rose immediately, followed by a very short time decrease before an other more sustained transient increase in $\left[\mathrm{Ca}^{2+}\right] i$ when PDGF was added. The Golgi apparatus and the rest of the cytoplasm show a

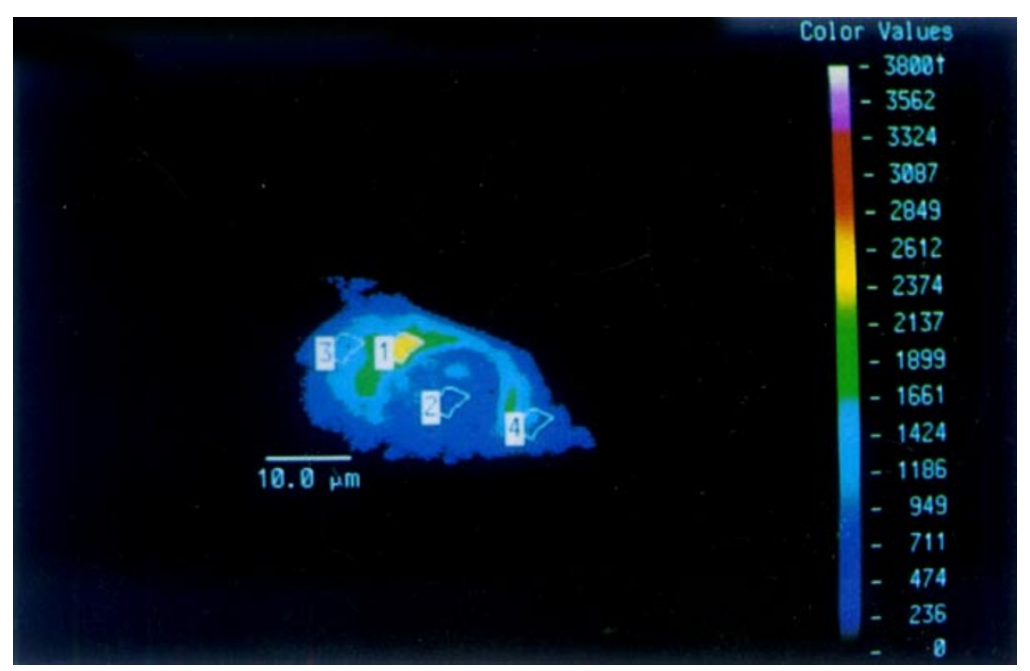

Fig 1. Visualization of the intracellular free $\mathrm{Ca}^{2+}$ by LSCM in a typical $2 \mathrm{BS}$ cell. Pseudocolor scale represents intensity of fluo-3 fluorescence excited at $488 \mathrm{~nm}$. Note that the highest $\left[\mathrm{Ca}^{2+}\right] i$ is found in the perinuclear region (area 1). Cell nucleus (area 2) showed a very low $\left[\mathrm{Ca}^{2+}\right] i$. The rest areas of the cytosol (area 3 and 4 ) showed a $\left[\mathrm{Ca}^{2+}\right] i$ between that in the perinuclear region and the cell nucleus.

Fig 2. > Co-localization of the subcellular distribution of free calcium and the Golgi apparatus in a single $2 \mathrm{BS}$ cell. The pseudocolor images showed that the highest $\left[\mathrm{Ca}^{2+}\right] i$ in perinuclear region is associated with the Golgi apparatus, a, the fluo-3 fluorescence of a middle optical section of a 2BS cell. b, C6-NBD-ceramide fluorescence of the same optical section, c and d showed a serial optical sections of fluo-3 fluorescence (c) or C6-NBD-ceramide fluorescence (d) through the same cell. 
Cui Jet al

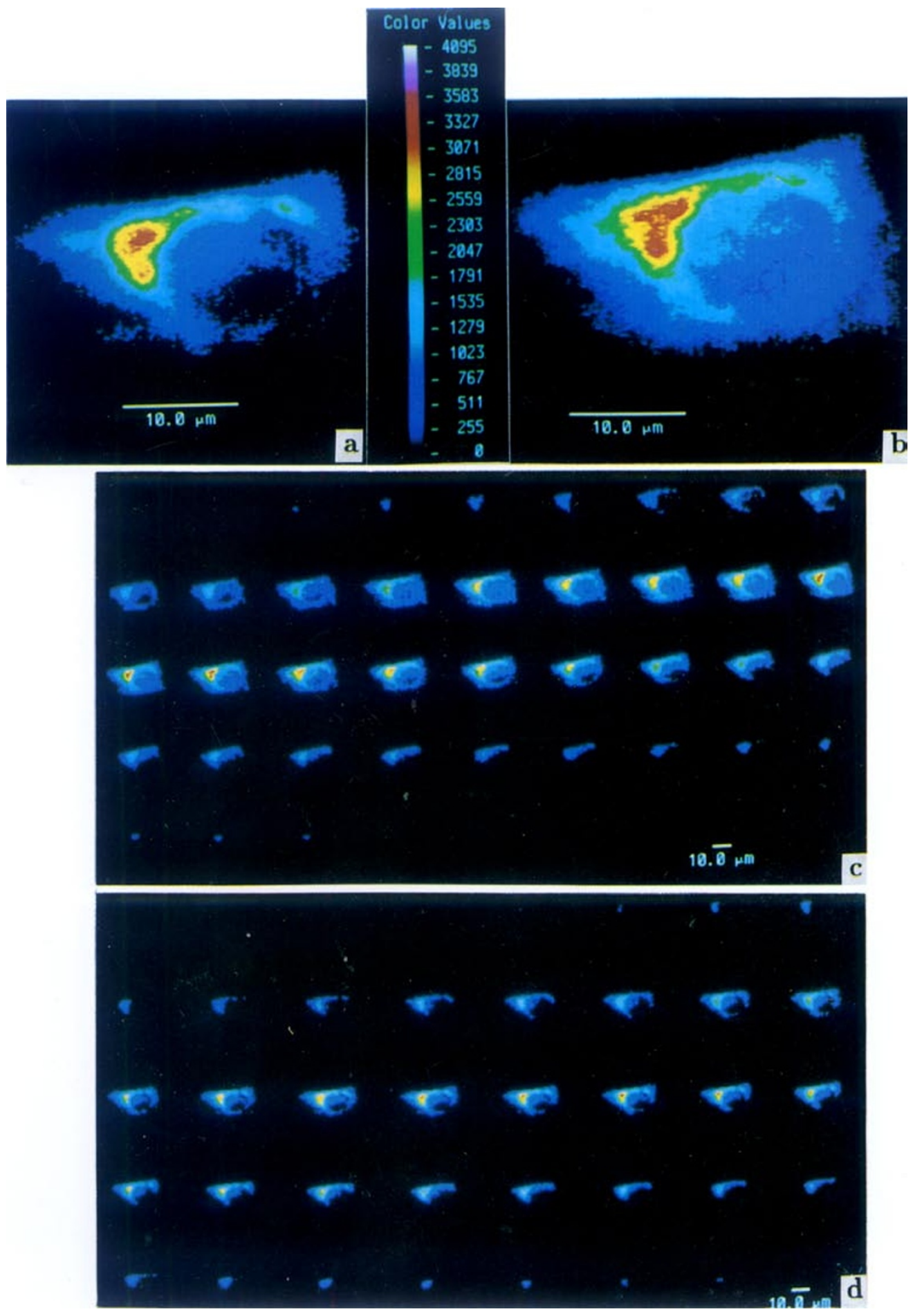


slower transient increase in $\left[\mathrm{Ca}^{2+}\right] i$ (Fig 3 , trace a, left column). In other cells (9 out of 15 cells), a different pattern occurred. At the time of the first nuclear $\left[\mathrm{Ca}^{2+}\right] i$ increase, the $\left[\mathrm{Ca}^{2+}\right] i$ in the Golgi apparatus showed a transient decrease and then recovered to the prestimulated level (Fig 3, trace b, right column). Meanwhile the $\left[\mathrm{Ca}^{2+}\right] i$ in the rest of the cytoplasm initially remained unchanged and then also increased simultaneously with the cell nucleus and the Golgi apparatus (Fig 3, traces $\mathrm{b}, \mathrm{d})$. The first increase in $\left[\mathrm{Ca}^{2+}\right] i$ in nucleus is faster than the second. It usually took less than 3 seconds to reach the peak level. The results demonstrate that the calcium of the first elevation in the nucleus came from the $\mathrm{Ca}^{2+}$ store of the Golgi apparatus. The transient decrease in $\left[\mathrm{Ca}^{2+}\right] i$ in the Golgi apparatus is so fast that in some cells this process can not be followed. The cell nucleus showed the fastest response to the mobilization of $\left[\mathrm{Ca}^{2+}\right] i$ when the calcium was released from the intracellular stores.

\section{Initiation and propagation of the $\mathrm{Ca}^{2+}$ waves by Thapsigargin treatment}

We next studied whether the Golgi apparatus could also participate in the calcium mobilization independent of $\mathrm{InsP}_{3}$ pathway. Thapsigargin (TG) is a plantderived tumour promoter that selectively blocks the $\mathrm{Ca}^{2+}$-ATPase pump of a nonmitochondrial intracellular $\mathrm{Ca}^{2+}$ pool. It appears to elevate cytosolic $\left[\mathrm{Ca}^{2+}\right] i$ and depletes InsP3- sensitive $\mathrm{Ca}^{2+}$ store in a variety of cells by a mechanism that does not involve hydrolysis of inositophospholipids[11-14]. When 2BS cells were exposed in a $\mathrm{Ca}^{2+}$-free medium, the elevation in $\left[\mathrm{Ca}^{2+}\right] i$ induced by TG was transient (Fig 4). $200 \mathrm{ng} / \mathrm{ml}$ TG caused a rapid $\left[\mathrm{Ca}^{2+}\right] i$ increase but a slow decay to basal level or even below. This may result from the inhibition of the internal $\mathrm{Ca}^{2+}$-ATPase. The rate of $\left[\mathrm{Ca}^{2+}\right] i$ increase induced by TG is slower than that caused by PDGF. Usually, it took 20-30 seconds to reach the peak level. Accurate time course images of TG induced $\mathrm{Ca}^{2+}$ waves were captured by LSCM. Pseudocolor fluorescence images of a $2 \mathrm{BS}$ cell challenged with $200 \mathrm{ng} / \mathrm{ml} \mathrm{TG}$ in $\mathrm{Ca}^{2+}$-free medium are shown in Fig 5 . Since the increase in $\left[\mathrm{Ca}^{2+}\right] i$ is slower, it was observed clearly that on stimulation with TG, the $\left[\mathrm{Ca}^{2+}\right] i$ initially rose at the site adjacent to the Golgi apparatus. The $\mathrm{Ca}^{2+}$ waves propagate from the Golgi apparatus toward the cell nucleus and finally throughout the whole cell. However, the $\left[\mathrm{Ca}^{2+}\right] i$ decay to its resting level in a

Fig 3. > Relative fluorescence intensity against time(s) plots of the response of a $2 \mathrm{BS}$ cell loaded with fluo-3/AM to the treatment of PDGF. Green, red, yellow and blue line represent the $\left[\mathrm{Ca}^{2+}\right] i$ within the Golgi apparatus, cell nucleus and two different regions of cytosol, respectively (areas were selected as shown in Fig 1). Arrows showed the time when PDGF was added. Fluorescence intensities were recorded at 0.230.0 second intervals. In the absence of extracellular $\mathrm{Ca}^{2+}, 6$ out of $15(40 \%)$ cells responded as typified by traces a and c, while the remaining cells responded as typified by traces $b$ and $d$. Traces $c$ and $d$ were the magnification of traces $a$ and $b$ at the time after addition of PDGF. 
Cui Jet al

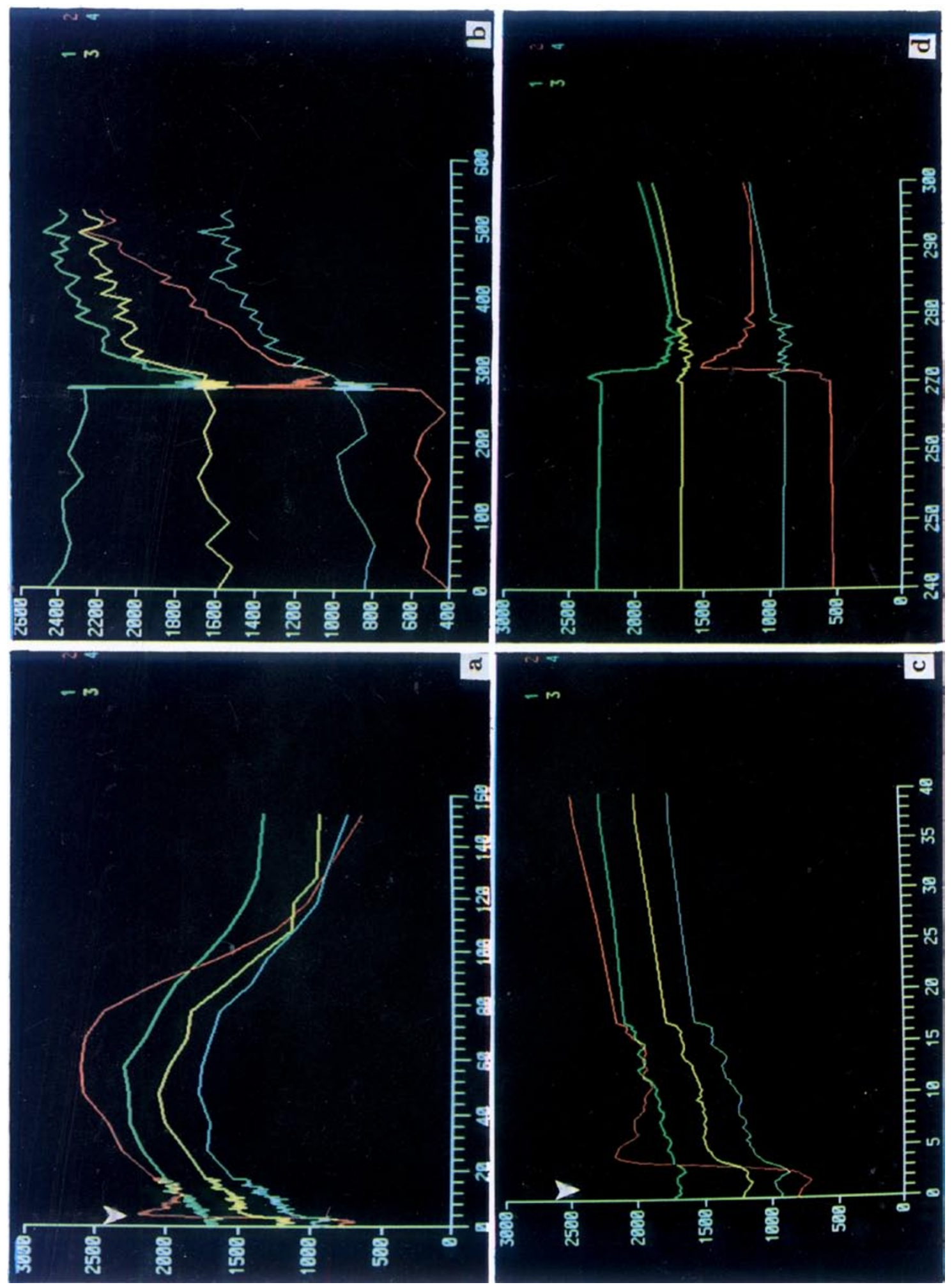


inverse pathway. All ten cells that responded with a TG-induced rise in $\left[\mathrm{Ca}^{2+}\right]_{i}$ showed a similar phenomenon. These results indicate that TG can mobilize $\mathrm{Ca}^{2+}$ release from the Golgi $\mathrm{Ca}^{2+}$ store. On stimulation with $\mathrm{TG}$, the cell nucleus also shows a notable response in $\left[\mathrm{Ca}^{2+}\right]_{i}$ mobilization.

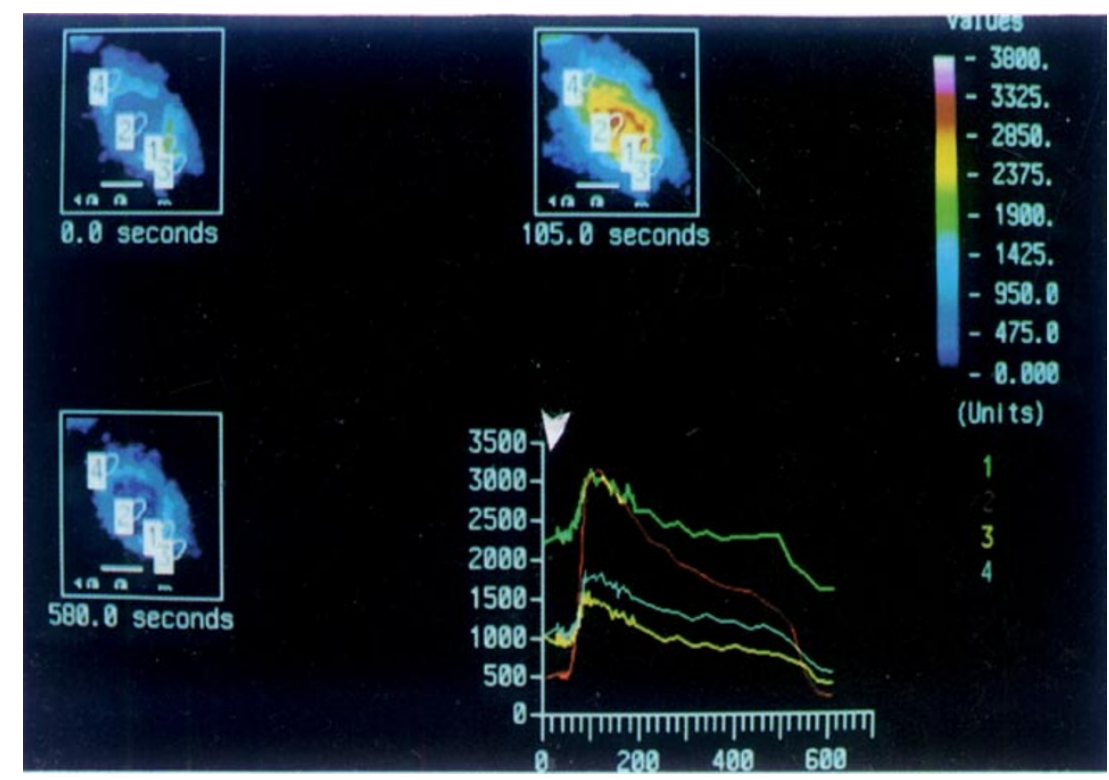

Fig 4. A typical time plot of changes in $\left[\mathrm{Ca}^{2+}\right]_{i}$ in a single $2 \mathrm{BS}$ cell loaded with fluo-3/AM in response to $200 \mathrm{ng} / \mathrm{ml}$ TG. Color lines represent the areas as described in Fig. Arrow indicated the time point when TG was added to solution.

\section{Change in $\left[\mathrm{Ca}^{2+}\right]_{i}$ in response to digitonin}

Previous work has demonstrated that $10 \mu M$ digitonin selectively permeablized the plasma membrane, whereas this concentration did not effect the internal membranes, such as the endoplasmic retiulum(ER), Golgi apparatus and mitochondrial membranes $[15,16]$. When cells were permeablized with 10-20 $\mu M$ digitonin, the fluorescences of $\mathrm{Ca}^{2+}$ probes always declined because of the efflux of the cytosolic free calcium $[1,17]$. In the present study, 2BS cells preloaded with fluo-3/AM were incubated in a $\mathrm{Ca}^{2+}$-free medium and then permeablized with $10 \mu \mathrm{M}$ digitonin. As shown in Fig 6, $10 \mu M$ digitonin triggered a transient sharp global $\left[\mathrm{Ca}^{2+}\right]_{i}$ increase followed by a large loss of $\mathrm{Ca}^{2+}$. It caused the $\left[\mathrm{Ca}^{2+}\right] i$ to decline far below its basal level. Digitonin also generated $\mathrm{aCa}^{2+}$ wave similar to TG stimulation. The $\left[\mathrm{Ca}^{2+}\right] i$ first increased in the Golgi apparatus and then throughout the cell, but digitonin almost completely depleted the intracellular $\mathrm{Ca} 2+$ store (Fig 6b). Similar response 
with a rise in $\left[\mathrm{Ca}^{2+}\right] i$ to $10 \mu M$ digitonin has been observed in five different experiments. Since it is unlikely that $10 \mu M$ digitonin permeablized the membrane of internal $\mathrm{Ca}^{2+}$ stores in such a short time, the result suggest that the decrease in $\left[\mathrm{Ca}^{2+}\right] i$ may also induce $\mathrm{Ca}^{2+}$ release from the intracellular stores.
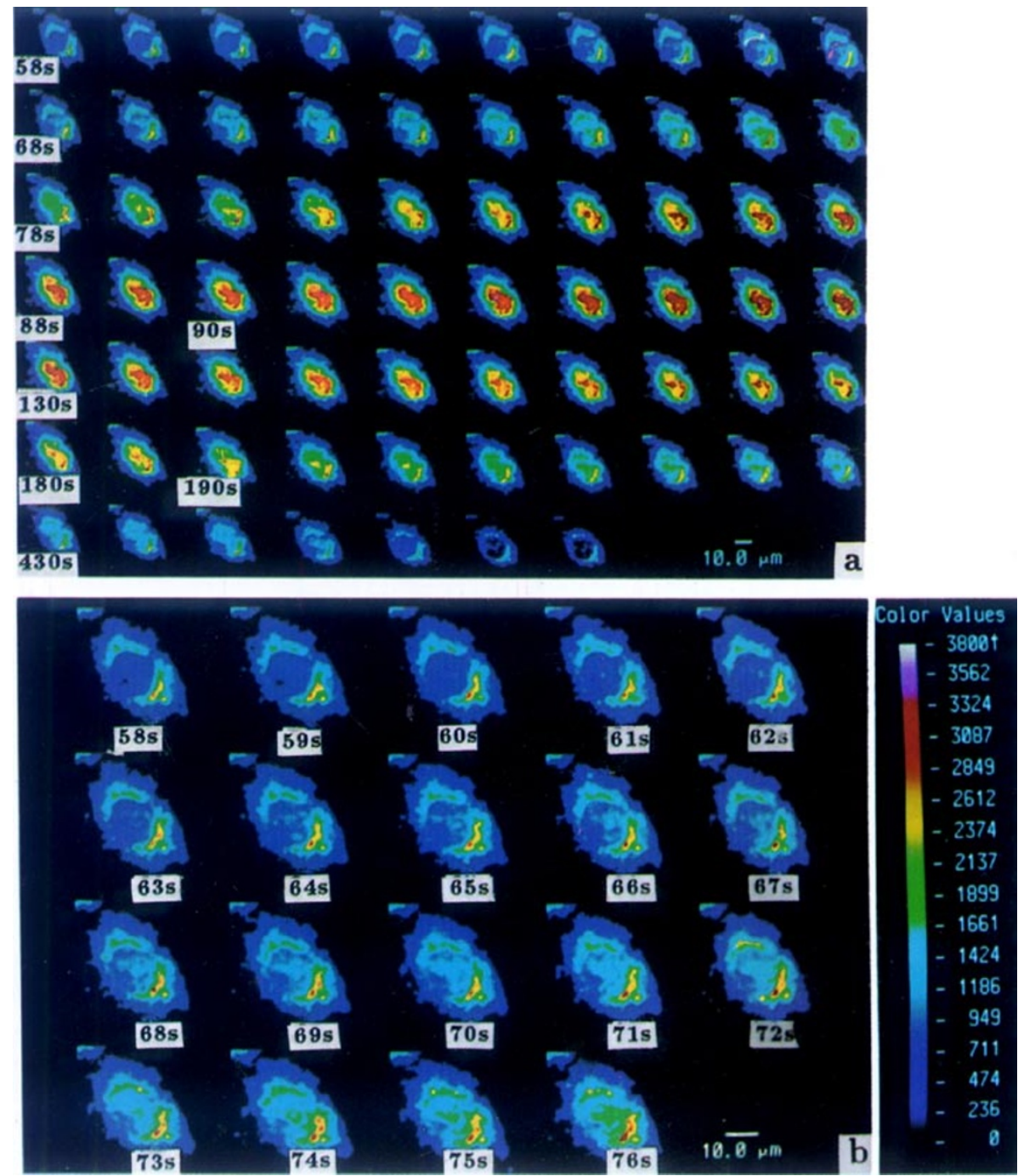

Fig 5. Visualization of the $\mathrm{Ca}^{2+}$ waves in a single $2 \mathrm{BS}$ cell in response to TG. Pseudocolor fluorescence images showed the initial rise in $\left[\mathrm{Ca}^{2+}\right] i$ was released from the Golgi apparatus. Note that the $\mathrm{Ca}^{2+}$ was finally retrieved into the same region. Images were captured at 1.0-30.0 second intervals. (b) is the magnification of (a) around the time addition of TG. TG was added at 35.2s. 
Golgi apparatus as an intracellular calcium store
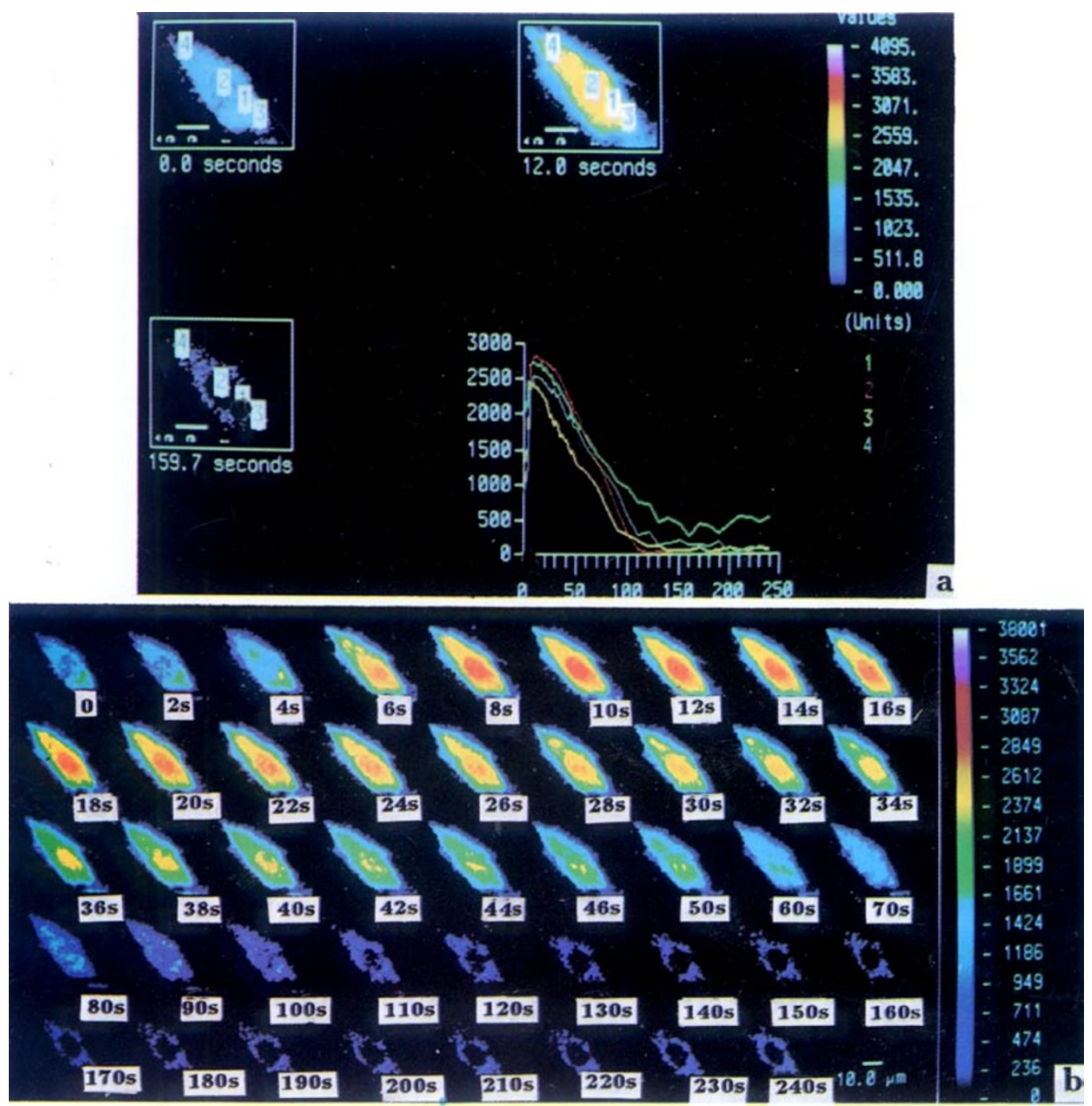

Fig 6. Kinetic plot and time-course images of a single $2 \mathrm{BS}$ cell in response to $10 \mu M$ digitonin. a, time plot of transient changes in $\left[\mathrm{Ca}^{2+}\right] i$ in response to $10 \mu M$ digitonin. Arrow marked the time point when digitonin was added. The images were obtained at 2.0 - 10.0 second intervals, $b$, pseudocolor images showed the changes in $\left[\mathrm{Ca}^{2+}\right] i$ around the time of digitonin stimulation. $10 \mu \mathrm{M}$ digitonin was added to the sample after scan 2 . Note that the calcium in the Golgi apparatus was also deleted by digitonin.

\section{DISCUSSION}

In the present report, we have investigated the spatiotemporal localization of intracellular $\mathrm{Ca}^{2+}$ associated with $\left[\mathrm{Ca}^{2+}\right]_{i}$ changes. In order to study the response of intracellular $\mathrm{Ca}^{2+}$ store upon agonists stimulation, all the experiments have been 
carried out in a $\mathrm{Ca}^{2+}$-free system. The effects of $\mathrm{Ca}^{2+}$ - ATPase pump and $\mathrm{Na}^{+}$$\mathrm{Ca}^{2+}$ exchanger on the plasma membrane are negligible since control experiments showed no $\left[\mathrm{Ca}^{2+}\right] i$ changes within five minutes when cells were exposed to a $\mathrm{Ca}^{2+}$ free medium or a $\mathrm{Ca}^{2+}$-free medium containing $10 \mu \mathrm{M}$ calmodulin inhibitor W7. Thus, the mobilization of $\left[\mathrm{Ca}^{2+}\right] i$ upon agonist stimulation only reflects the activity of intracellular calcium store. In order to visualize the spatiotemporal $\left[\mathrm{Ca}^{2+}\right] i \mathrm{mo}$ bilization in response to agonists, we used the LSCM to monitor subcellular changes in $\left[\mathrm{Ca}^{2+}\right] i$ in single cell. The results indicate that the Golgi apparatus is an intracellular $\mathrm{Ca}^{2+}$ store in $2 \mathrm{BS}$ cells. First, the highest $\left[\mathrm{Ca}^{2+}\right] i$ is associated with the Golgi apparatus (Fig 2). Second, PDGF initially induced a $\mathrm{Ca}^{2+}$ release from the Golgi apparatus (Fig 3). Third, in response to TG, the $\mathrm{Ca}^{2+}$ waves first arise from and then return to the Golgi apparatus (Fig 5). Recently, it has been also shown that the Golgi apparatus contains considerable total calcium and that it has a rapidly exchanging pool of calcium $[4,18]$. In many cell types, an elevated activity of $\mathrm{Ca}^{2+}$ ATPase has been found in the Golgi apparatus [19, 20]. From these results, it is speculated that the Golgi apparatus may play some role in the regulation of $\mathrm{Ca}^{2+}$ for signal transduction besides its role in exocrine function[21-23].

Different subcellular patterns of $\mathrm{Ca}^{2+}$ release in response to PDGF, TG and digitonin have been shown in the present work. There is no question that PDGFinduced $\left[\mathrm{Ca}^{2+}\right] i$ increase is mediated by InsP3. As for the biphasic changes in nuclear $\mathrm{Ca}^{2+}$, it is suggested that the first sharp spike in $\left[\mathrm{Ca}^{2+}\right] i$ is caused by the rapid $\mathrm{Ca}^{2+}$ release from $\operatorname{InsP}_{3} \mathrm{R}$ channel of the Golgi apparatus. The second elevation in $\left[\mathrm{Ca}^{2+}\right] i$ is always slower than that of the initial $\left[\mathrm{Ca}^{2+}\right] i$ elevation in response to PDGF. Some cells responded to PDGF so rapidly that we could not observed the calcium released from the Golgi apparatus. But in some slow response cells, it shows clearly that $\mathrm{Ca}^{2+}$ is released from Golgi apparatus and transferred to the nucleus.

Experiments using TG and digitonin showed that both of them can trigger an explosive release of $\mathrm{Ca}^{2+}$ from the internal stores independent $\mathrm{InsP}_{3}$ pathway. It has been observed that cells possess a constant leak of $\mathrm{Ca}^{2+}$ through $\mathrm{Ca}^{2+}$ channels of the internal stores[24-27]. It has also been reported that the $\mathrm{InsP}_{3}$-sensitive channel can spontaneously release $\mathrm{Ca}^{2+}$ through a mechanism similar to $\mathrm{Ca}^{2+}$ induced $\mathrm{Ca}^{2+}$ release (CICR)[28]. The function of the leak is not clear, but it seems to be a fundamental property of the agonist sensitive intracellular $\mathrm{Ca}^{2+}$ store. Normally, the leak is almost entirely matched by the reuptake into the internal $\mathrm{Ca}^{2+}$ stores. The $\mathrm{Ca}^{2+}$-ATPase of the internal store is extremely efficient in recycling the $\mathrm{Ca}^{2+}$ that leaks from the store into the cytoplasm. Fig 7 shows a model for Golgi calcium store. There is an equilibrium between free calcium ions and the binding calcium in the store. Besides the $\mathrm{InsP}_{3} \mathrm{R}$ channel, there is a constant $\mathrm{Ca}^{2+}$ leak from the Golgi calcium store. PDGF can open the InsP $\mathrm{P}_{3} \mathrm{R}$ channel mediated by $\mathrm{InsP}_{3}$ and $\mathrm{Ca}^{2+}$ release through $\left[\mathrm{Ca}^{2+}\right] i$ gradient. The decrease of $\mathrm{Ca}^{2+}$ in Golgi store leads to the separation of $\mathrm{Ca}^{2+}$ from its binding protein and more $\mathrm{Ca}^{2+}$ can release from the store. $\mathrm{Ca}^{2+}$ can be re-uptaken into Golgi apparatus by $\mathrm{Ca}^{2+}$-ATPase. TG 
inhibits the $\mathrm{Ca}^{2+}$-ATPase of the internal $\mathrm{Ca}^{2+}$ store and the leaked $\mathrm{Ca}^{2+}$ can not go back into the Golgi $\mathrm{Ca}^{2+}$ store, which also leads to a decrease of $\mathrm{Ca}^{2+}$ in the store. Digitonin induces $\left[\mathrm{Ca}^{2+}\right] i$ increase by a similar pathway. The leaking $\mathrm{Ca}^{2+}$ flows out through the pores on the plasma membrane and can not be recycled into the internal calcium store either. This also causes a decrease of the stored $\mathrm{Ca}^{2+}$ and then triggers the internal stores to release their calcium until they are depleted. It seems that not only an increase in $\left[\mathrm{Ca}^{2+}\right] i$ can generate CICR $[9,29]$, but a decrease in stored $\mathrm{Ca}^{2+}$ can also do so.

Although it has been observed that there is a highest $\mathrm{Ca}^{2+}$ fluorescence at the perinuclear area in various cell types, most of the authors consider it as the result of dye compartmentalization of the ester loaded indicator into internal organelles[30]. It is widely believed that ester loaded $\mathrm{Ca}^{2+}$ fluorescent indicators tend to be sequestered into subcellular compartments and distort cytoplasmic free $\mathrm{Ca}^{2+}$ due to different dye concentrations in different cell regions. However, up to now, there is no direct evidence showing that the high fluorescence at the Golgi area (or perinuclear area) is due to high concentration of free calcium or due to high concentration of dye in it, although the possibility that the concentration of free calcium in this area is really higher than that of the cytosol can not be excluded. In addition, it is more difficult to elucidate the kinetic changes of fluo-3 fluorescence in the Golgi region in response to agonists by dye compartmentalization since the concentration of fluo-3 in it could not change in such a short time (less than $1 \mathrm{~min}$ ). Connor[31] thought that much of the change in the organelle was an accumulation, not a release, of $\mathrm{Ca} 2+$ following the $\mathrm{InsP}_{3}$ injection. And the Golgi apparatus was a conspicuous early site for such accumulation. To the contrary, our results demonstrated clearly that the Golgi apparatus was the only area where fluo-3 fluorescence decrease by PDGF addition (Fig 3). And in most cases of agonist-stimulation, the increase of fluo-3 fluorescence in Golgi area is usually less than that in any other area of the cell. So neither an accumulation of $\mathrm{Ca}^{2+}$, nor the excretion of dye sequestrated in the Golgi apparatus can be the cause of these mobilization. Only the calcium ions released from and the Golgi apparatus can explain the fluorescent decrease in Golgi area. Perhaps it is fluo-3 sequestration in the Golgi apparatus that made it possible to measure the different changes between the Golgi $\mathrm{Ca} 2+$ and cytosolic $\mathrm{Ca}^{2+}$. Even if it could not indicate the "real" $\mathrm{Ca}^{2+}$ level because of dye compartmentalizaton, it shows the real changes of calcium in response to agonists between the Golgi apparatus and the cytosol. Therefore, our results indicated that Golgi apparatus really play some role in the regulation of $\mathrm{Ca}^{2+}$ in signal transduction pathway.

It is notable that the cell nucleus shows a remarkable response to the change of $\left[\mathrm{Ca}^{2+}\right] i$. Our results reveal that the nucleus contains lower $\left[\mathrm{Ca}^{2+}\right] i$. In the previous work, it has also been observed that the total calcium in the nucleus is very low [4]. It is impossible for the nucleus to be an intracellular $\mathrm{Ca}^{2+}$ store since both its binding and free calcium are very low. Therefore, the increase or decrease of nuclear 

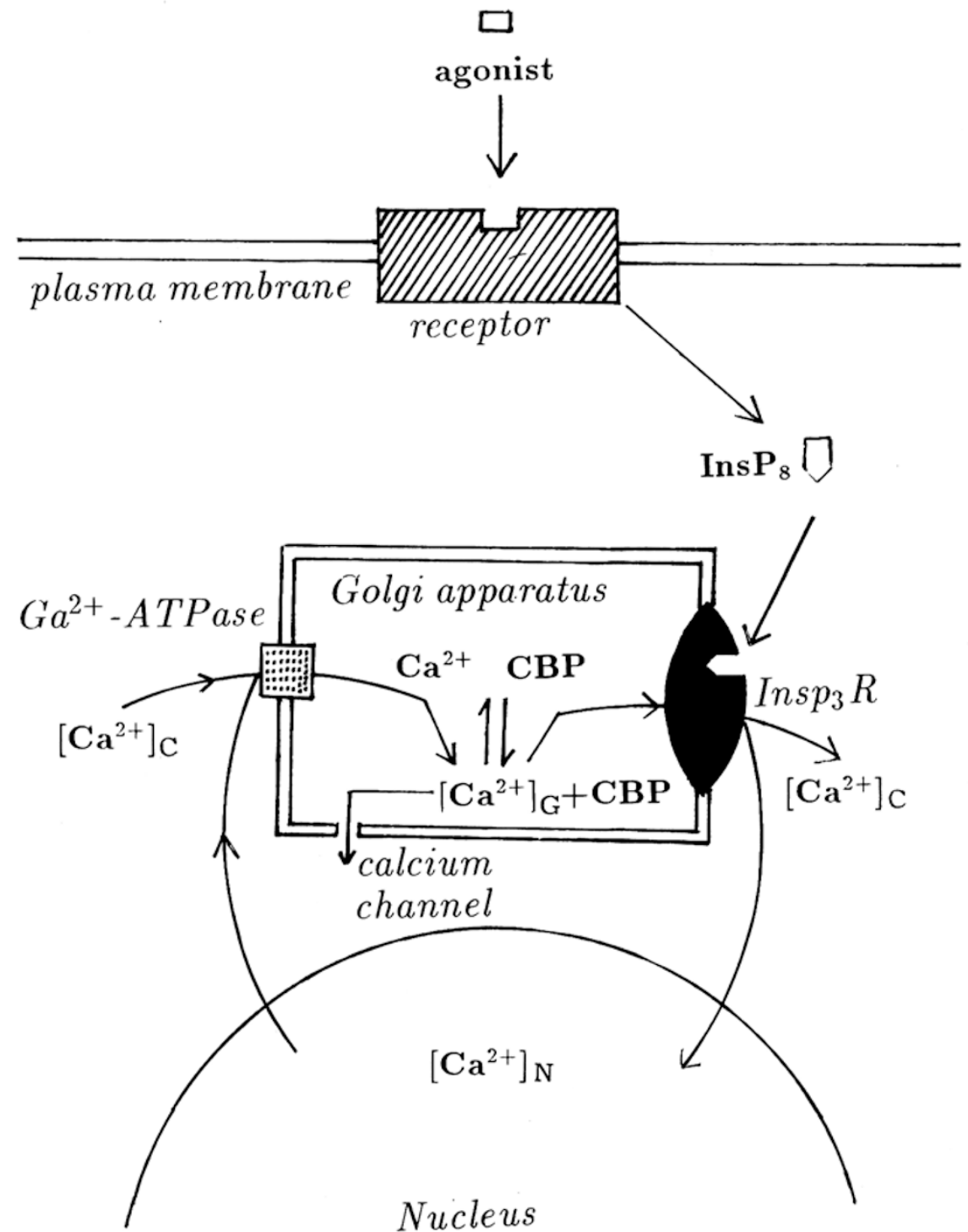

Fig 7. A model for the pattern of Golgi calcium store. More details are outlined in the discussion. CBP: calcium binding protein. $\left[\mathrm{Ca}^{2+}\right] \mathrm{g}$ : concentration of calcium in Golgi apparatus, $\left[\mathrm{Ca}^{2+}\right]$ c: concentration of calcium in cytosol, $\left[\mathrm{Ca}^{2+}\right] \mathrm{n}$ : concentration of calcium in nucleus. 
calcium can be regarded as a sign which reflects a dynamic change of the release or refilling of intracellular calcium store.

This work has demonstrated that the Golgi apparatus is a functional $\mathrm{Ca}^{2+}$ store. What is the significance of the Golgi $\mathrm{Ca}^{2+}$ store, how does it regulate $\mathrm{Ca}^{2+}$ homoeostasis and what are the protein molecules and mechanisms for the Golgi apparatus to be $\mathrm{a} \mathrm{Ca}^{2+}$ store etc. are all important questions that should be answered in the future.

\section{ACKNOWLEDGEMENTS}

We thank Dr Peter K Hepler (Biology Department, University of Massachusetts) for critical reading and for his useful comments on this manuscript. We also thank Dr HQ Zhang and M Fang for preparing the photographs. We are grateful to Meridian Instruments Inc for providing available laser scanning confocal microscope and technical help. This work was supported by grants from the National Education Committee Doctor's Foundation of China and grants from the National Natural Science Foundation of China.

\section{REFERENCES}

[1] Himpens B, Smedt H DE, Droogmans G, Casteels R. Differences in regulation between nuclear and cytoplasmic $\mathrm{Ca}^{2+}$ in cultured smooth muscle cells. Am J Physiol 1992; 263 (cell physiol 32):C95-C105.

[2] Cheek TR, Morgan AO, Sullivan A J, Moreton RB, Berridge M J, Burgoyne RD. Spatial localization of agonist-induced $\mathrm{Ca}^{2+}$ entry in bovine adrenal chromaffin cells. J Cell Sci 1993; 105:913-21.

[3] Kasai H, Li YX, Miyashita Y. Subcellular distribution of $\mathrm{Ca}^{2+}$ release channels underlying $\mathrm{Ca}^{2+}$ waves and oscillations in exocrine pancreas. Cell 1993; 74:669-77.

[4] Chandra S, Kable EPW, Morrison GH, Webb WW. Calcium sequestration in the Golgi apparatus of cultured mammalian cells revealed by laser scanning confocal microscopy. J Cell Sci 1993;100:747-52.

[5] Vidulescul C, Onicescu D, Popescu M, Martin S. Ultrastructural localization of calcium in the Golgi apparatus of two different cell types. Romanian J Morphol Embryol 1991; 37:3-6.

[6] Wahl M, Sleight RG, Gruenstein E. Association of cytoplasmic free $\mathrm{Ca}^{2+}$ gradients with subcellular organelles. J Cell Physiol 1992; 150: 593-609.

[7] Xue SB, Nicoud MR, Cui J, Jovin A. High concentration of calcium ions in Golgi apparatus. Cell Res. 1994; 4:97-108.

[8] Lipsdy NG, Pagano RE. A vital stain for the Golgi apparatus. Science 1985; 228:745-7.

[9] Berridge MJ. Inositol trisphosphate and calcium signalling. Nature 1993; 361:315-25.

[10] Pouyssegur J, Seuwen K. Transmembrane receptors and intracellular pathways that control cell proliferation. Annu Rev Physiol 1992; 54:195-210.

[11]Blackmore PF. Thapsigargin elevates and potentiates the ability of progesterone to increase intracellular free calcium in human sperm: possible role of perinuclear calcium. Cell Calcium 1993; 14:53-60.

[12]Authi KS, Bokkala S, Patel Y, Kakkar VV, Munkonge F. Ca ${ }^{2+}$ release from platelet intracellular stores by thapsigargin and 2, 5-di-(t-butyl) -1,4- benzohydroquinone: relationship to $\mathrm{Ca}^{2+}$ pools and relevance in platelet activation. Chem J 1993; 294:119-26. 
[13] Thastrup O, Cullen P J, Drobak BK, Hanley MR, Dawson AP. Thapsigargin, a tumor promoter, discharges intracellular $\mathrm{Ca}^{2+}$ stores by specific inhibition of the endoplasmic reticulum $\mathrm{Ca}^{2+}$. ATPase. Proc Natl Acad Sci USA 1990; 87:2466-70.

[14] Gericke M, Droogmans G, Nilius B. Thapsigargin discharges intracellular calcium stores and induces transmembrane currents in human endothelial cells. Pflugers Arch 1992; 422:552-7.

[15] Niemen AL, GoresGJ, Dawson TL, Herman B, Lemasters JJ. Toxic injury from mercury chloride in rat hepatocytes. J Biol Chem 1991; 265:2399-408.

[16] Lemasters J J, Nieminen AL, Gores GJ, et al. Multiparameter digitized video microscopy (MDVM) of hypoxic cell injury. In: Optical Microscopy for Biology, B. Herman and K. Jacobsen eds. (Wiley-Liss, Inc.) 1990: pp. 523-41.

[17] Hofer AM, Machen TE. Technique for in situ measurement of calcium in intracellular inositol 1, 4, 5-trisphosphate-sensitive stores using the fluorescent indicator mag-fura-2. Proc Natl Acad Sci USA 1993; 90:2598-602.

[18] Chandra S, Ausserer WA, Morrison GH. Subcellular imaging of calcium exchange in cultured cells with ion microscopy. J Cell Sci 1992; 102:417-25.

[19] Mughal S, Cuschieri A, AL-Bader AA. Intracellular distribution of $\mathrm{Ca}^{2+}-\mathrm{Mg}^{2}+$ adenosine triphosphatase (ATPase) in various tissues. J Anat 1989; 162:111-24.

[20] Antebi A, Fink GR. The yeast calcium -ATPase homologue, PMR1 is required for normal Golgi function and localizes in a novel Golgi-like distribution. Mol Biol Cell 1992; 3:633-54.

[21] Yoshimoto A, Nakanishi K, Anzai T, Komine S. Effects of inositol 1,4,5-trisphosphate on calcium release from the endoplasmic reticulum and Golgi apparatus in mouse mammary epithelial cells: a comparison during pregnancy and lactation. Cell Biochem Func 1990; 8:191-8.

[22] Frick TW, Spycher MA, Heitz PU, Okagaki T, Goodale RL. Ultrastructure of the guinea pig pancreas in acute hypercalcemia. Pancreas 1992; 7:287-94.

[23] Bingham EW, Mcgranaghan, MB, Wickham ED, Leung CT, Farrell HMJR. Properties of (calcium plus magnesium) adenosine triphosphatases in the Golgi apparatus and microsomes of the lactating mammary glands of cows. J Dairy Sci 1993; 76:393-400.

[24 Thastrup O, Dawson AP, Scharff O, et al. Thapsigargin, a novel molecular probe for studying intracellular calcium release and storage. Agents Actions 1989; 27:17-23.

[25] Takemura H, Hughes AR, Thastrup O, Putney JWJ. Activation of calcium entry by the tumor promoter thapsigargin in parotid acinar cells. J Biol Chem 1989; 264:12266-71.

[26] Chew CS, Petropoulos AC. Thapsigargin potentiates histamine- stimulated HCL secretion but does not mimic cholinergic responses. Cell regul 1991; 2:27-39.

[27] Ely JA, Ambroz C, Baukal A J, Christensen SB, Balla T, Catt KJ. Relationship between agonist and thapsigargin-sensitive calcium pools in adrenal glomerulosa cells. J Biol Chem 1991; 266:18635-41.

[28] Missiaen L, Taylor CW, Berridge MJ. Spontaneous calcium release from inositol triphosphatesensitive calcium stores. Nature 1991; 352:241-4.

[29] Tsien RW, Tsien RY. Calcium channels, stores, and oscillations. Annu Rev Cell Biol 1990; 6:715-60.

[30] Meldolesi J, Madeddu L, Pozzan T. Intracellular $\mathrm{Ca}^{2+}$ storage organelles in non-muscle cells: heterogeneity and functional assignment. BBA 1990; 1055:130-40.

[31] Conner JA. Intracellular calcium mobilization by inositol 1, 4, 5-triphosphate: Intracellular movements and compartmentalization. Cell Calcium 1993; 14:185-200.

Received 7-2-1995. Revised 28-6-1995. Accepted 17-9-1995 